\title{
REPRESENTATION OF HOBBESIAN THEORY IN THE FILM SERIES “SQUID GAME” IN THE VIEW OF GENERATION Z
}

\author{
Adryan Allen G. W., Albert Louis, Jovita Anggi Taruli, \& Nurmalita Sari \\ Bandung Institute of Technology \\ Email: adryan.gerald@gmail.com
}

\begin{abstract}
'Squid Game' is a film series from South Korea that is in high demand lately. This film tells the story of a group of people who are in debt and end up participating in a game competition that puts their lives on the line to earn money. This game is designed by a frontman who manages to avoid chaos during the game. Each player has also signed an agreement/contract while at the game venue. In this paper, we will discuss the representation of the running of politics and government within the scope of the country from the film series 'Squid Game' based on the social-political theory of Thomas Hobbes. This research was conducted by means of literature studies and surveys. Based on the results of data analysis, there are things in this film that can describe the politics and government of the country. Frontman describes the position of a leader of a country, players describe the position of citizens, game contracts describe the laws of the country thatmust be obeyed, and the game place describes the territory of a country. This film also describes social conflicts that may occur among the people, proletarian rebellions, and the government's way of dealing with conflicts with dictatorial systems, democracy, and others. From the research results, readers can see this film from a different perspective and can better understand the world of politics and state government.
\end{abstract}

Keywords: 'Squid Game', politic, country, government, Hobbesian

\begin{abstract}
Abstrak
Squid Game adalah serial film dari Korea Selatan yang sangat diminati akhir-akhir ini. Film ini bercerita tentang sekelompok orang yang berhutang dan akhirnya berpartisipasi dalam kompetisi game yang mempertaruhkan nyawa mereka untuk mendapatkan uang. Game ini dirancang oleh frontman yang berhasil menghindari kekacauan selama pertandingan. Setiap pemain juga telah menandatangani perjanjian/kontrak saat berada di tempat permainan. Dalam makalah ini, kita akan membahas representasi jalannya politik dan pemerintahan dalam lingkup negara dari seri film 'Squid Game' berdasarkan teori sosial-politik Thomas Hobbes. Penelitian ini dilakukan melalui studi literatur dan survei. Berdasarkan hasil analisis data, ada hal-hal dalam film ini yang bisa menggambarkan politik dan pemerintahan negara. Frontman menggambarkan posisi seorang pemimpin suatu negara, pemain menggambarkan posisi warga negara, kontrak permainan menggambarkan hukum negara yang harus dipatuhi, dan tempat permainan menggambarkan wilayah suatu negara. Film ini juga menggambarkan konflik sosial yang mungkin terjadi di antara rakyat, pemberontakan proletar, dan cara pemerintah menangani konflik dengan sistem diktator, demokrasi, dan lain-lain. Dari hasil penelitian, pembaca dapat melihat film ini dari perspektif yang berbeda dan dapat lebih memahami dunia politik dan pemerintahan negara bagian.
\end{abstract}

Kata kunci: 'Squid Game', politik, negara, pemerintah, Hobbesian

\section{INTRODUCTION}

Film can be a medium to describe a situation in real life. According to Sutanto (2017: 3) and (Nurgiansah, 2021) film is a medium to channel artistic expression in the form of story ideas from artists or filmmakers. The ideas obtained by these artists are sometimes inspired by events in real life. One of the films that is currently popular is 'Squid Game'.
'Squid Game' is a film series originated from South Korea. This series tell about a group of people who participate in a game with the lure of getting a lot of money prizes. However, behind the attractive prizes they have to risk their lives. The game 'Squid Game' is designed by a frontman who leads the game and manages to avoid chaos as the game progresses. During the game, participants must obey the rules made by 
the organizer, if they commit a violation and lose the game, the participant will be punished. This can be a picture of a country. Players are like people. The people have an important element as one of the governing agents of the government. Where in the film series 'Squid Game' if there are no players, the game will not run. Like wise with politics and government if there are no people. This shows that even in the film there is a complete country with political and government representatives.

According to Thomas Hobbes, political representation is something that the government can use to control someone continuously even from generation to generation which can lead to something absolute (Mar'ah, 2017) and (Nurgiansah, 2020). Political representation has a meaning, namely the values, interests, and goals represented by the political system, especially those in the executive branch. There are 3 factors related to political representation. The first is the person who is represented, the second is the person who is given the mandate, and the third is the processed form of the interests of those who represent and be represented (Dewantara \& Nurgiansah, 2021a) (Dewantara et al., 2021) (Dewantara \& Nurgiansah, 2021b). Political representation can occur in different units such as in social and regional matters. And there are also representations of substance and descriptive representations. So that issues arise regarding political representation in terms of democracy in the name of elections

The purpose of this study is to prove whether it is true that there is political representation and state government according to Hobbes' theory in the film series 'Squid Game'. By knowing this, the public is expected to better understand and be more aware of a series that may contain meanings that are not in accordance with current norms.

\section{RESEARCH METHODS}

Research on Representation of Hobbesian Theory in the Film Series "Squid Game" in the View of Generation Z is a quantitative-based research. This study collects data using the Google Form platform which is distributed among Generation Z throughout Indonesia.

The question data is submitted with the concept of a questionnaire consisting of questions with a range of number answers. Answer range of numbers is intended to determine the level of agreement of the respondents to the questions asked. Numbers range from one to four, with one indicating the lowest level of agreement, and four being the highest level of agreement with the questions asked. The choice of answer options is intended to ensure the respondent's absolute agreement with the questions asked.

The data obtained from the proposed questionnaire will be processed and discussed further in the Results and Discussion section. The processed data is displayed in the form of bar charts and pie charts for easy reading and data processing. The data that has been obtained will then be analysed and produce conclusions on the research carried out.

To support the various arguments presented in this study, a literature study was conducted using various journal articles relevant to the topic of this research (Nurgiansah \& Al Muchtar, 2018)(Nurgiansah et al., 2020) (Rachman et al., 2021).

\section{RESEARCH RESULTS \& DISCUSSION Reaearch Result Respondents Profile}

From 101 respondents, the profile of respondents and their distribution are as follows: 
Usia

101 jawaban

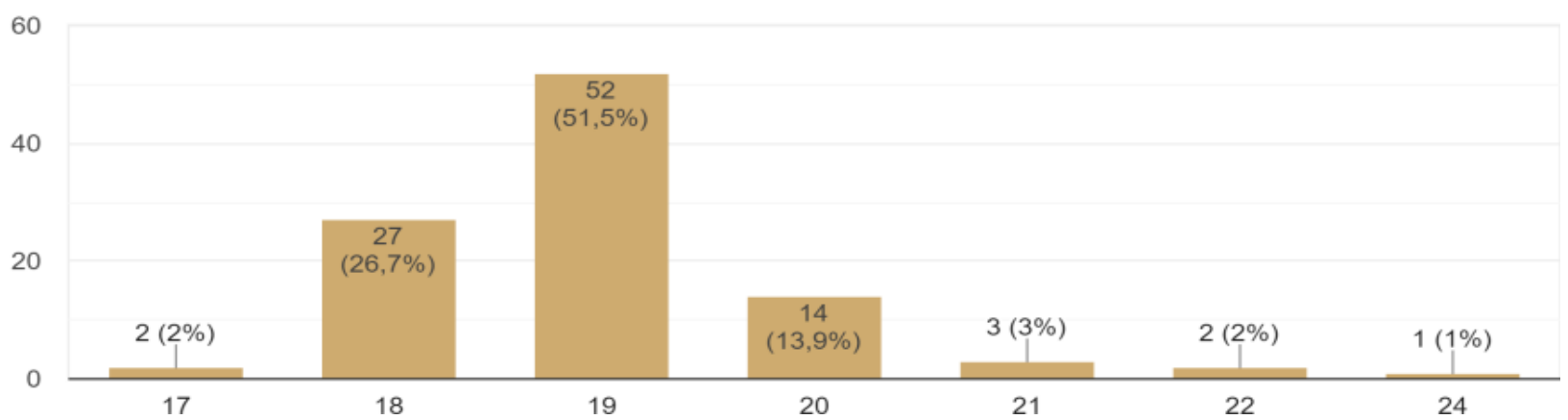

Figure 1. Respondents age distribution

\section{Asal Provinsi}

101 jawaban

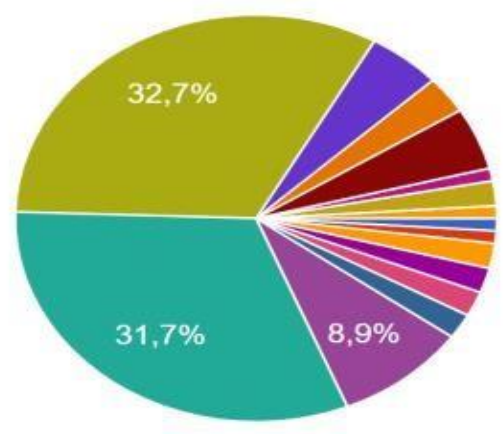

1. Nanggroe Aceh Darussalam.

2. Sumatera Utara.

3. Sumatera Barat.

4. Riau.

5. Kepulauan Riau.

6. Jambi.

7. Sumatera Selatan.

8. Kepulauan Bangka Belitung.

Figure 2. Percentage of respondents from various regions

Table 1. Tabulation of the percentage of respondents from various regions

\begin{tabular}{|c|c|c|c|}
\hline Region & $\%$ & Region & $\%$ \\
\hline Jawa Barat & 32,7 & Kepulauan Riau & 2 \\
\hline DKI Jakarta & 31,7 & Sumatera Selatan & 2 \\
\hline Banten & 8,9 & Sumatera Barat & 2 \\
\hline Jawa Tengah & 5 & Sumatera Utara & 1 \\
\hline Jawa Timur & 5 & Nanggroe Aceh Darussalam & 1 \\
\hline DI Yogyakarta & 3 & Kalimantan Timur & 1 \\
\hline Sulawesi Selatan & 2 & Papua & \\
\hline Lampung & 2 & & \\
\hline
\end{tabular}


Udah nonton squid game belom nih??

101 jawaban

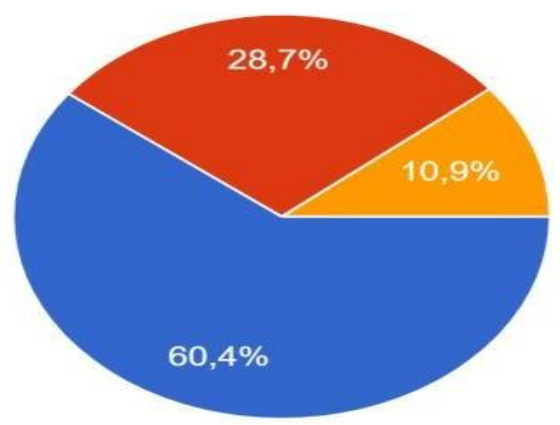

Tamat

Belum Sama sekali

Belom selesai

Figure 3. Percentage of respondents who have watched the 'Squid Game' series

Based on the questionnaire result, respondents from the questionnaire have an age distribution profile between 17-24 years and the majority are from West Java and DKI Jakarta, followed by Banten, Central Java, and East Java, all of which are included in the 10 most populous provinces in Indonesia (Badan Pusat Statistik, 2020). As many as $60.4 \%$ of respondents have finished watching the 'Squid Game' series, $10.9 \%$ have started watching but have not finished the series, and $28.7 \%$ have not watched it at all. To generalize the respondents' understanding of the film, we included a film synopsis that summarizes the storyline and background of the film in the questionnaire.

\section{Discussion}

\section{The Representation of Hobbesian Theory in the 'Squid Game'}

From the results of data collection from 101 samples of respondents from different provinces and ages. Researchers obtained the following data:

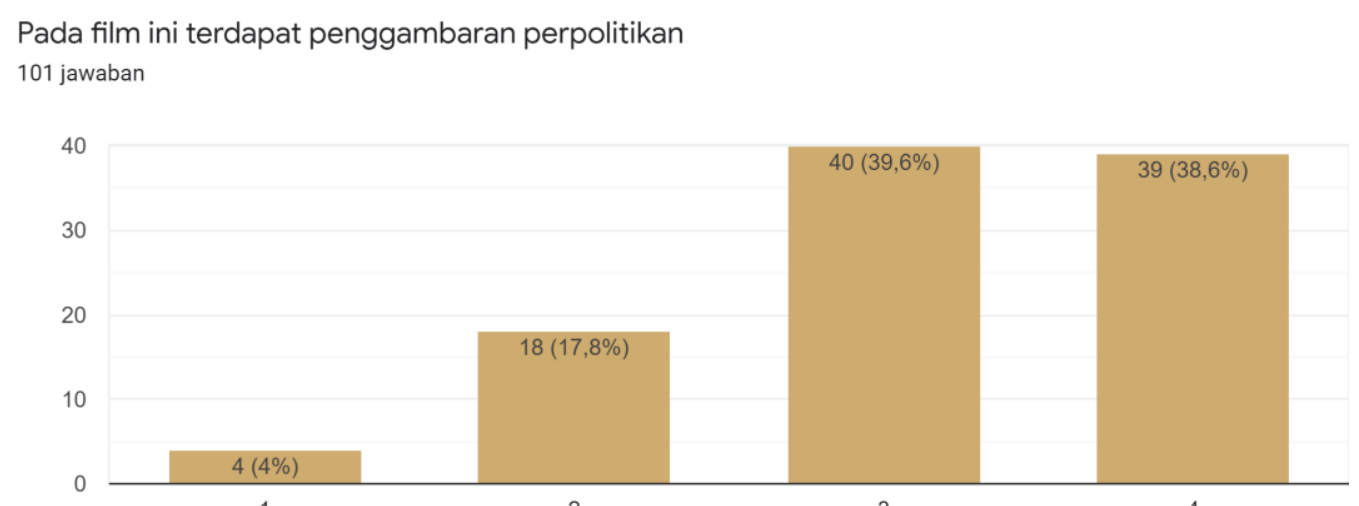

Figure 4. Response results related to the representation of politics in the 'Squid Game' series

From the results, it was found that the majority stated that there was a political figure in this film with $78.2 \%$ of respondents agreeing (39 people strongly agree and 40 people agreed) and $21.8 \%$ of respondents disagreed (4 people strongly disagree and 18 people disagree) with this statement.

These results relate to the three core variables used to conclude that the 'Squid Game' series depicts Thomas Hobbes' political theory, namely the state of nature, social contract, and the concept of the state. 
Pada film ini terdapat penggambaran pemerintahan suatu negara

101 responses

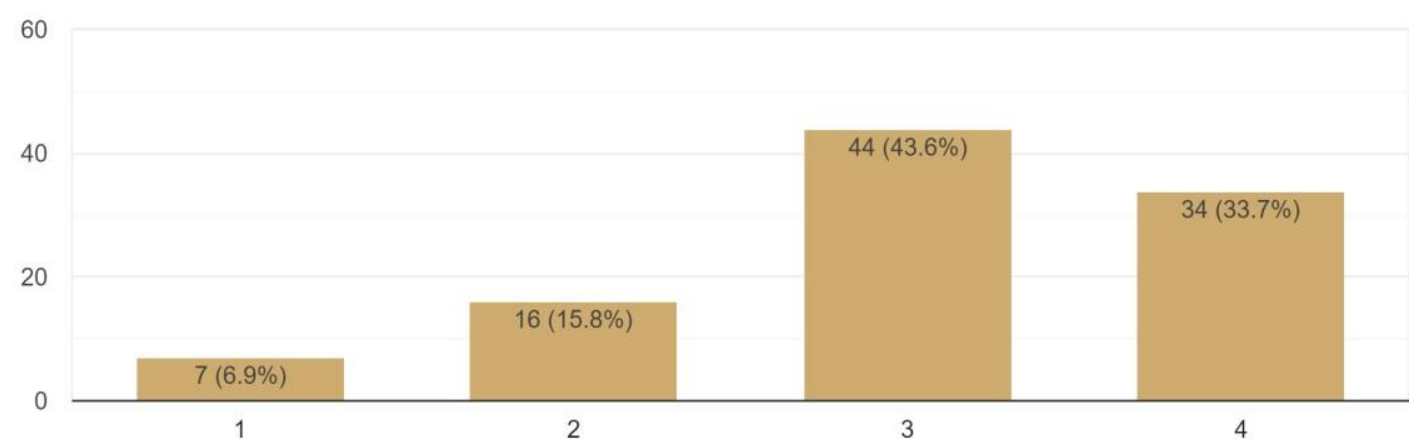

Figure 5. Response results related to the representation of a country's government in the 'Squid Game' series

From the results obtained, $77.3 \%$ of respondents chose to agree (44 people agreed and 34 strongly agreed) that there was a representation of the government of a country in this 'Squid Game' series, and $22.7 \%$ of respondents chose to disagree $(7$ people strongly disagree and 16 people disagree). agree) with this statement from these results, it is true that the representation of an authoritarian state government called Leviathan can be seen from the actions of the game organizers. They control and frighten players, and officers who are masked in circles, triangles or squares, easily kill players who fail or lose in completing the game.

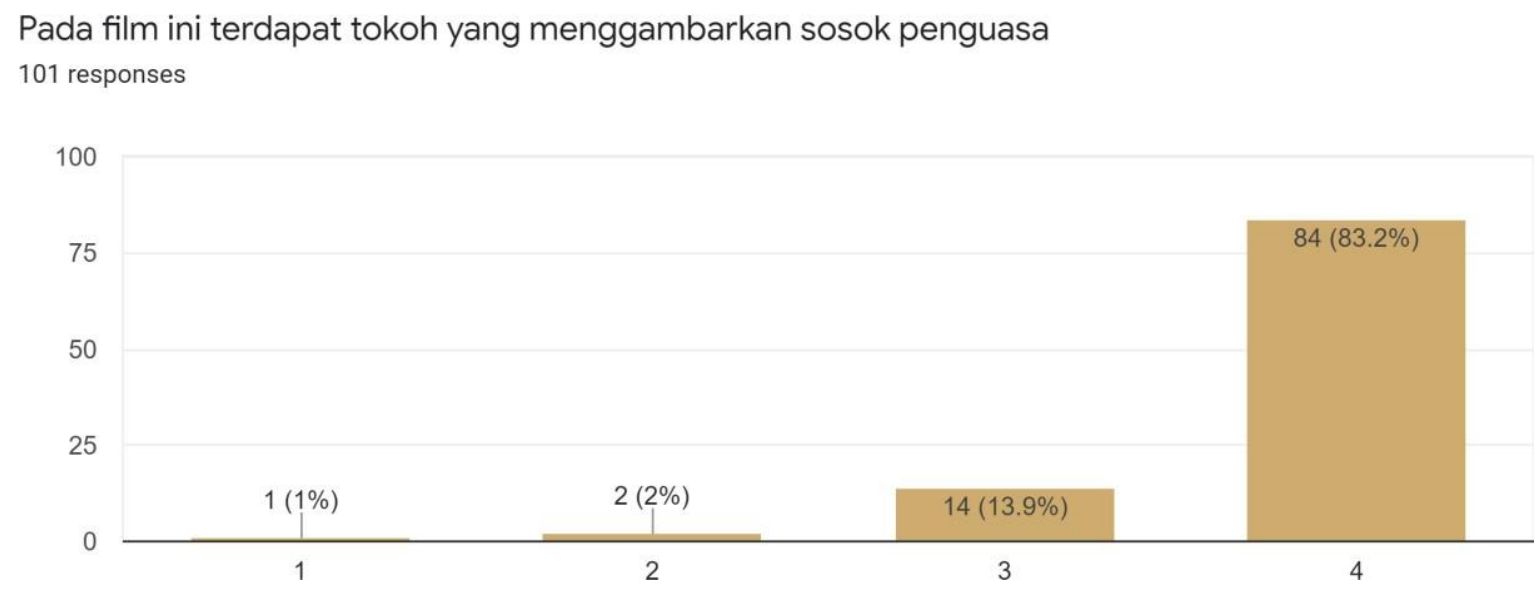

Figure 6. Related response results to the representation of a ruler in the 'Squid Game' series

From the results obtained, $97 \%$ of respondents chose to agree (14 people agree and 84 strongly agree) that there is a figure of ruler in the 'Squid Game' series, and $3 \%$ of respondents chose to disagree 1 person strongly disagree and 2 people disagree) with this statement.
From the results obtained, it is true that there is a figure of a ruler in this film, this ruler figure is also known as The Front Man. This ruler who makes the rules of every game, has the right to kill masked officers who disobey the rules, and is authoritarian. 
Film ini menggambarkan ketundukan sekelompok orang

101 responses

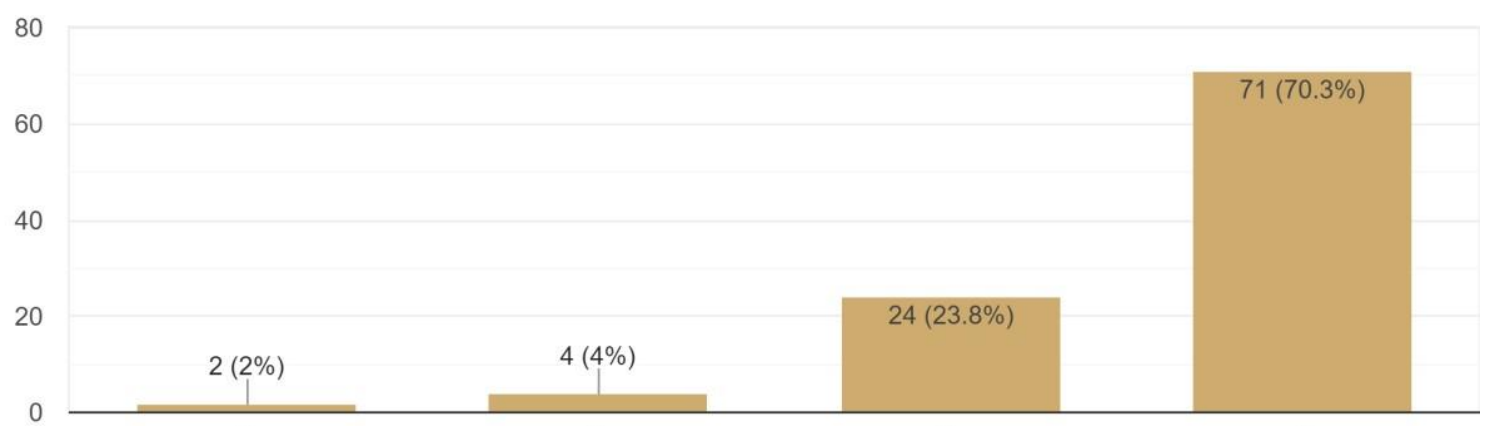

Figure 7. Related response results Figure ơ subjugation of a grỏup of people in the 'Squid Game' series

From the results obtained, $94 \%$ of respondents chose to agree (24 people agreed and 71 strongly agreed) that there was a submissive figure of a group of people in this 'Squid Game' series, and 6\% of respondents chose to disagree (2 people strongly disagree and 4 people disagree). agree) with this statement.

From the results of this survey, it is true that a group of people who are in debt who participate in the game 'Squid Game' must submit to a ruler and his officers. If they dared to act to break the rules, their lives were not safe.

\section{Pada film ini terdapat suatu perjanjian antara sosok penguasa dengan kelompok yang ditundukkan 101 responses}

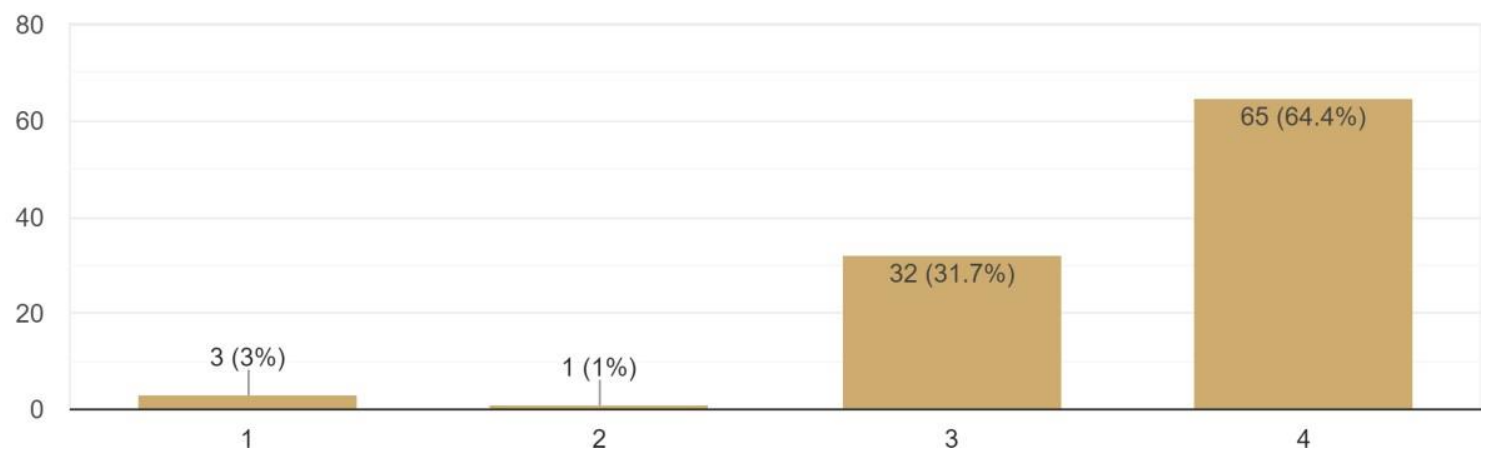

Figure 8. Response results related to the agreement between a ruler and a group of peoplewho submit to him in the 'Squid Game' series

From the results obtained, $96 \%$ of respondents chose to agree (32 people agreed and 65 strongly agreed) that there was a submissive figure of a group of people in this 'Squid Game' series, and 4\% of respondents chose to disagree (3 people strongly disagree and 1 person disagreed). agree) with this statement.

From the survey results, it is true that there is an agreement between these players and the ruler as long as the game has not been terminated. In that contract, there are three articles that are announced before the game starts. Article 1, players may not stop playing. Article 2, players who refuse to play will be eliminated. Article 3, the game will be stopped if the majority of participants agree. 


\begin{abstract}
Dalam film ini, pemain Squid Game no.218 Sang-Woo yang terdapat di foto 1 mengikuti teori Hobbes tentang state of nature 101 responses
\end{abstract}

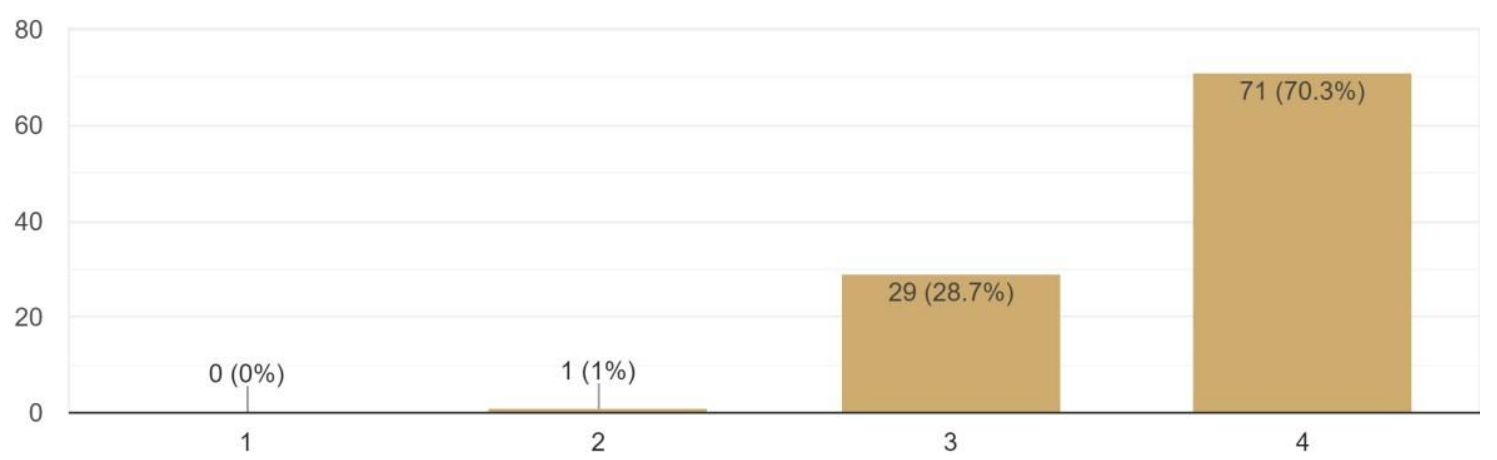

Figure 9. Related response results Sang-Woo follows Hobbes' theory of the state of nature in the 'Squid Game' series

From the results obtained, $99 \%$ of respondents chose to agree (29 people agreed and 71 strongly agreed) that SangWoo followed Hobbes' theory of the state of nature in the 'Squid Game' series, and 1\% of respondents chose to disagree (1 person disagreed). with this statement.

State of nature is simply an attempt to defend oneself. This self-defense effort makes humans hostile to other humans (homo homini lupus). The most visible representation is when in the game, they kill each other, either directly or in a structured way in order to survive and of course also win the game and get 45.6 billion won to pay off their debt. One of the players named Sang-Woo has also directly killed his game partner.

\title{
Dalam film ini, pemain Squid Game no.456 Gi-Hun yang terdapat di foto 2 mengikuti teori Hobbes tentang state of nature \\ 101 responses
}

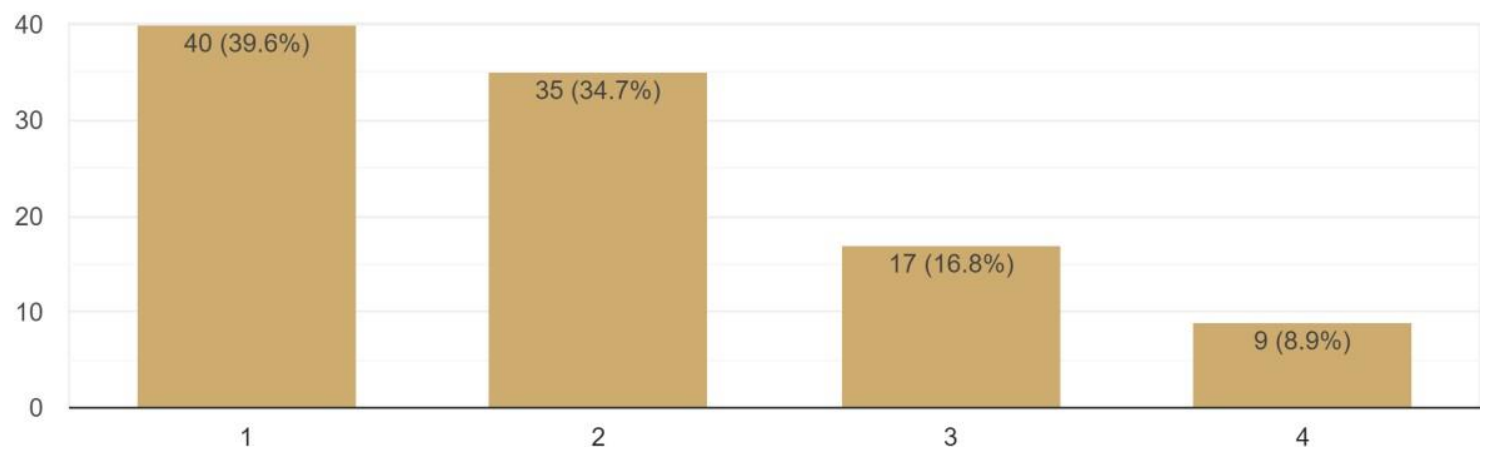

Figure 10. Related response results Gi-Hun follows Hobbes' theory of state of nature in 'Squid Game' series

From the results obtained, $25.7 \%$ of respondents chose to agree (17 people agreed and 9 strongly agreed) that SangWoo followed Hobbes' theory of the state of nature in the 'Squid Game' series, and
$74.3 \%$ of respondents chose to disagree $(40$ people strongly disagree and 35 people disagree) with this statement.

If we look closely, not all of the participants showed a cruel, selfish, and 
ruthless attitude like Jang Deok Soo, the player number 101. Gi Hun the player number 456, for example, he didn't even use the 45.6 billion won prize he got after winning the game. Gi Hun also forbade someone who got the 'Squid Game' business card to join the game.

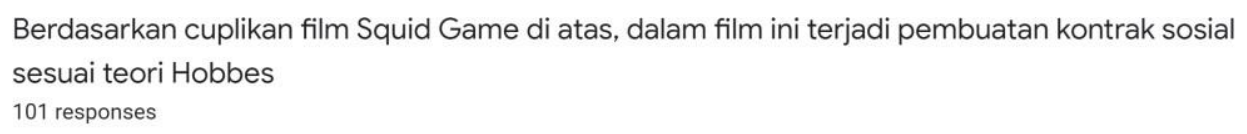

60

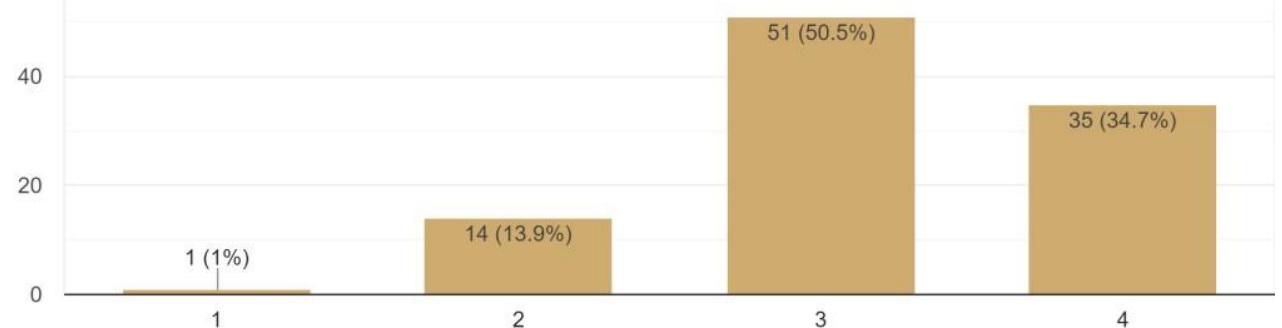

Figure 11. Related response results the creation of a social contract according to Hobbes' theory in the 'Squid Game' series

From the results obtained, $85 \%$ of respondents chose to agree (51 people agreed and 35 strongly agreed) that a social contract was made according to Hobbes theory in the 'Squid Game' series, and 15\% of respondents chose to disagree (1 person strongly disagreed and 14 people disagree) with this statement.

It was true that the players made a contract or rather an agreement with the organizer of the game. There are three articles signed before starting the game. Article 1 players are not allowed to stop playing. Article 2 players who refuse to play will be eliminated. Article 3 the game can be stopped if the majority agrees. Contracts are also indirectly made with the organizers of the game, the rich people in gold masks. If you successfully complete the six deadly games provided, players will get 45.6 billion wonworth of money.

\section{Berdasarkan foto di atas, pembuatan kontrak sosial tidak sesuai dengan teori Hobbes karena membuat pemain tidak merasa aman \\ 101 responses}

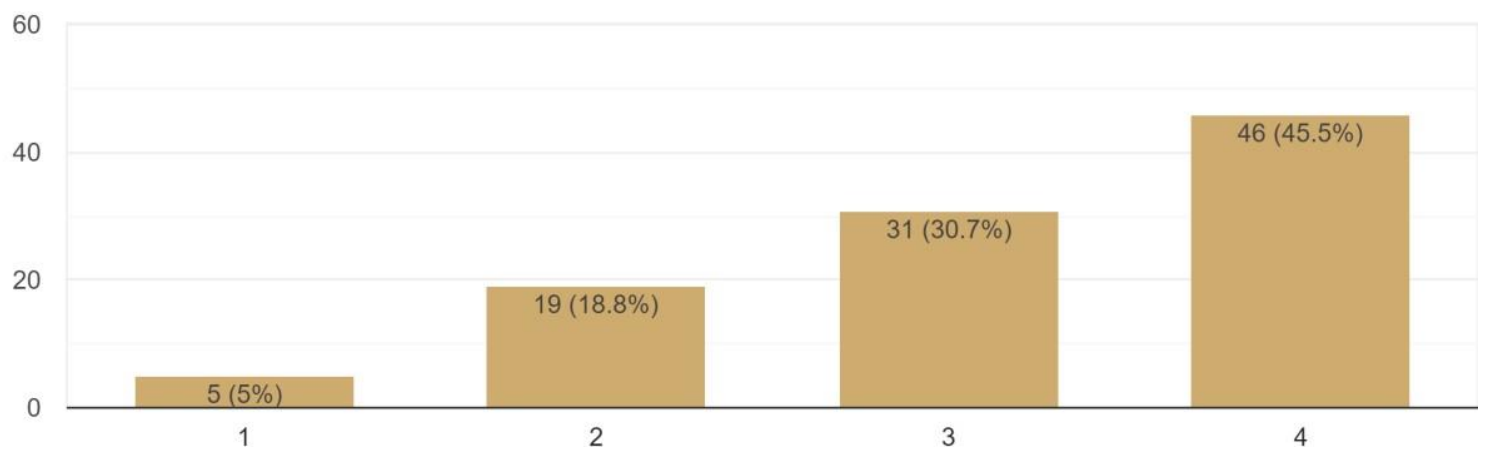

Figure 12. The results of the response related to making a social contract do not matchHobbes' theory because players do not feel safe in the 'Squid Game' series

From the results obtained, $76.2 \%$ of respondents chose to agree (31 people 
agree and 46 strongly agree) that making social contracts is not according to Hobbes theory because players do not feel safe in this 'Squid Game' series, and 23.8\% of respondents choose to disagree (5 people). strongly disagree and 19 people disagree) with this statement.

Indeed, 'Squid Game' does not show Hobbes's explanation of the social contract. In Hobbes's explanation, the social contract is made by the community with the state or authority by giving full freedom or rights, so the right to live and feel safe should be fulfilled. Unlike the 'Squid Game' which does not protect the rights of the participants after signing the agreement. In the actual social contract, the state is obliged to protect the life of the people who have given their freedom or rights.
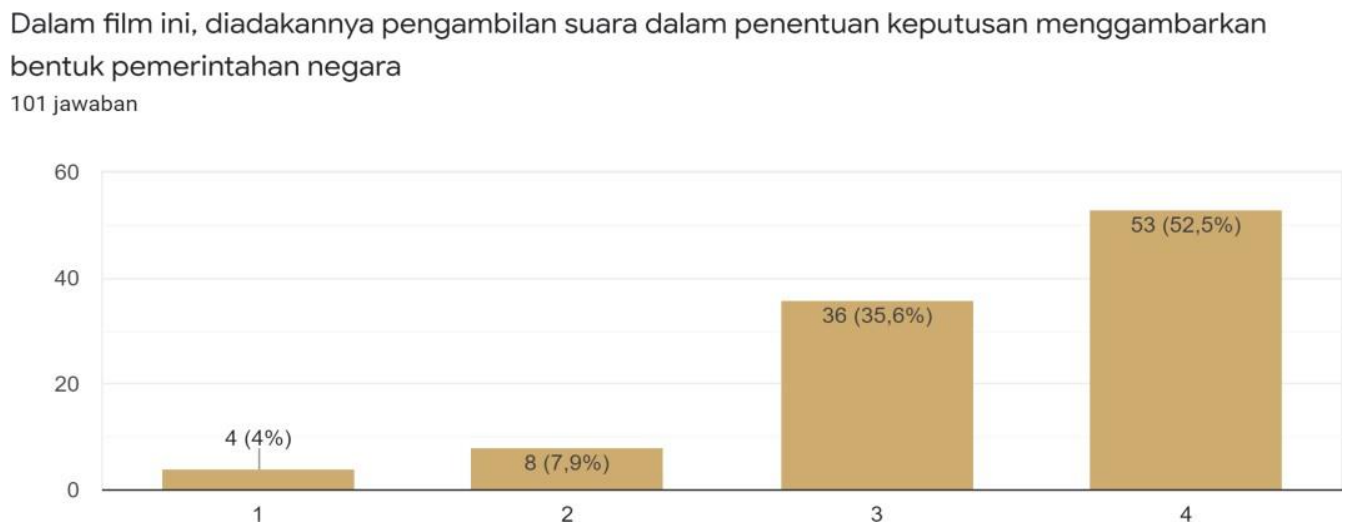

Figure 13. Related response results voting in making decisions in the 'Squid Game' series

From the results obtained, $88.1 \%$ of respondents chose to agree (36 people agreed and 53 strongly agreed) that there was a vote in determining decisions in the 'Squid Game' series and $11.9 \%$ of respondents chose to disagree (4 people strongly disagree and 8 people disagree) with this statement.

From the survey results, it is true that a vote was taken to decide whether the game would continue or not. The masked officers were also fair and involved in bringing order at the time, by prohibiting any commotion or other forms of violence that would change a person's decision. The existence of voting like this is not in accordance with Hobbes' theory. According to Hobbes, the decision is entirely left to the leader.

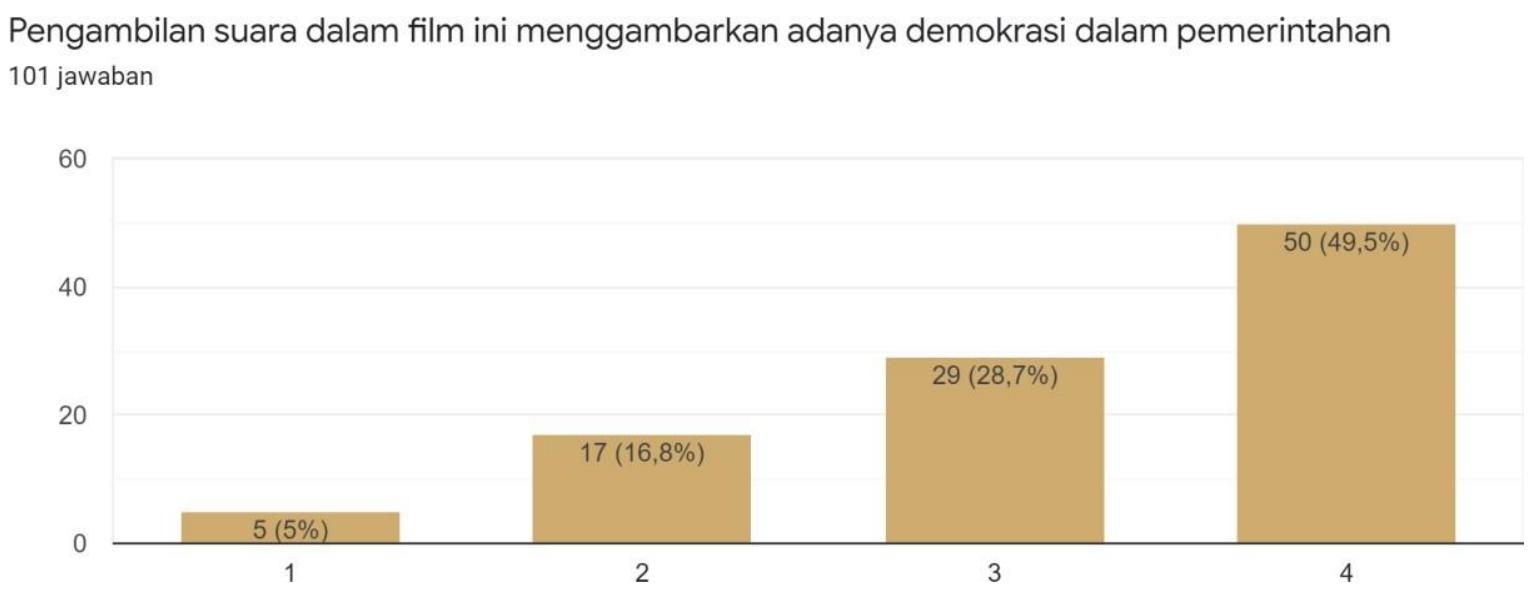

Figure 14. Related response results voting depicts democracy in 'Squid Game' series 
From the results obtained, $78.2 \%$ of respondents chose to agree (29 people agreed and 50 strongly agreed) that there was a vote in determining decisions in the 'Squid Game' series that was not in accordance with Hobbes' theory because according to the theory of decisions came from the leader, and $21,8 \%$ of respondents chose to disagree (5 people strongly disagree and 17 people disagree) with this statement.
From the results obtained, $78.2 \%$ of respondents chose to agree (29 people agreed and 50 strongly agreed) that there was a vote in determining decisions in the 'Squid Game' series that was not in accordance with Hobbes' theory because according to the theory of decisions came from the leader, and 21, 8\% of respondents chose to disagree (5 people strongly disagree and 17 people disagree) with this statement.

\section{Berdasarkan foto di atas, dalam film ini sosok penguasa bertindak otoriter 101 jawaban}

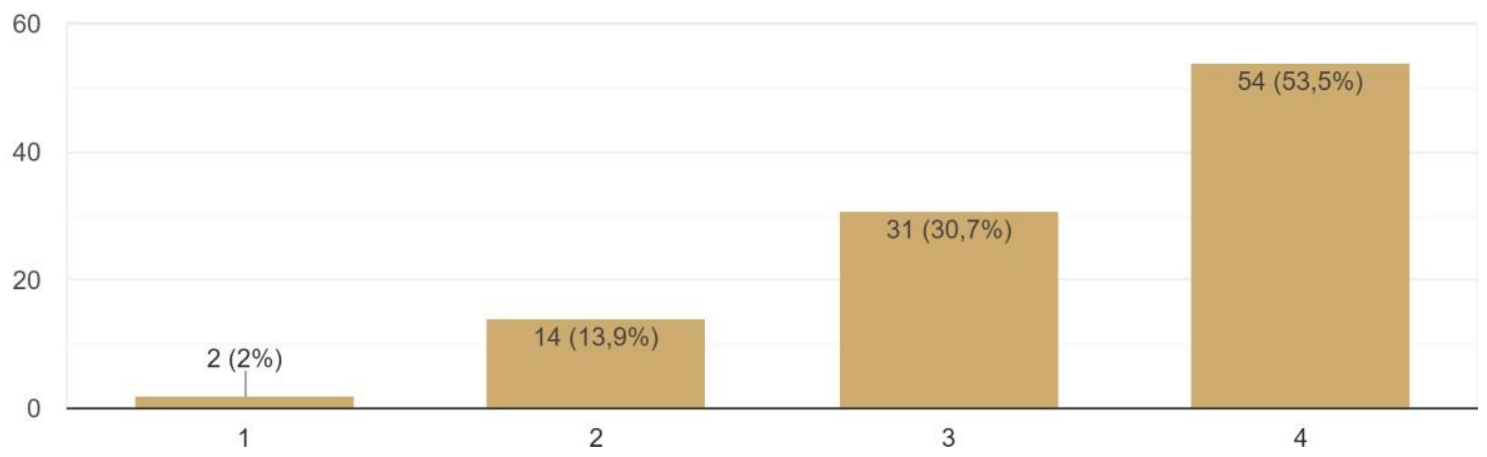

Figure 15. Related response results ruler acting authoritarian in 'Squid Game' series

From the results obtained, $84.1 \%$ of respondents chose to agree (31 people agree and 54 strongly agree) that the leader in the 'Squid Game' series acts authoritarian, and $15.9 \%$ of respondents chose to disagree (2 people strongly disagree and 14 people disagree) with this statement. In this series the leader figure without hesitation to shoot dead his own subordinates and players who are proven to have cheated in the game.

In Hobbes' theory of statehood, in order for the people to be orderly, the state must be scary so that people have a fear of death. However, being scared to death didn't mean they could decide whether a person could live or die. This is contrary to Hobbes' theory.

Berdasarkan foto di atas, dalam film ini sosok penguasa bertindak sewenang-wenang
101 jawaban

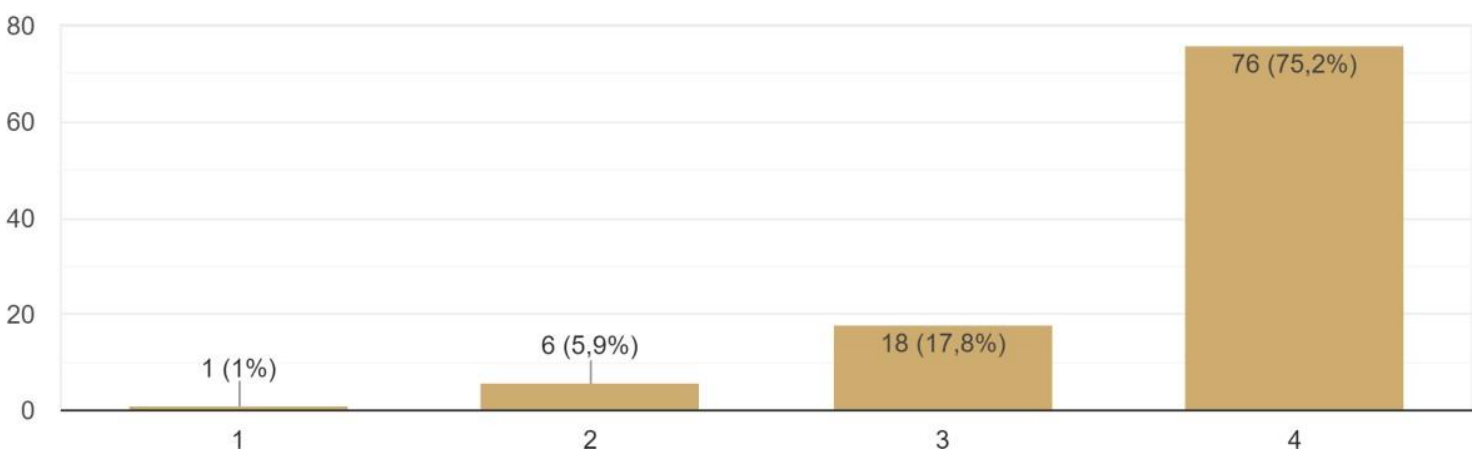

Figure 16. Related response results arbitrary ruler in the 'Squid Game' series 
From the results obtained, $84.1 \%$ of respondents chose to agree (18 people agreed and 76 strongly agreed) that the leader in the 'Squid Game' series acted arbitrarily, and $6.9 \%$ of respondents chose to disagree (1 person strongly disagreed). agree and 6 people disagree) with this statement. From the survey results, almost all agree about the arbitrariness of the leader.

In the series, the leader unilaterally changes the rules of the game just because his client finds it boring. In his theory Hobbes states that leaders cannot act arbitrarily in running a government that can harm the people. Therefore, this is contrary to Hobbes' theory of statehood.

\section{CONCLUSION}

The film series 'Squid Game' in its storyline is very thick with the figure of the political system. Figures appear in this film series when the 'Squid Game' is played. The interaction between players, as well as between organizers and players presents various elements of political philosophy. Some of them are presented with figures that are similar to the socio- political theory by
Thomas Hobbes. Thomas Hobbes has the concept that humans have a state of nature, which encourages them to make a social contract, and submit themselves under a government like a state. However, the state must be scary in order to be obeyed by the people to achieve common goals.

Overall, the results of the questionnaire show that most Generation $\mathrm{Z}$ in Indonesia agree that this series depicts the human condition and the running of government according to Thomas Hobbes' theory. However, after further criticism, there are several things in the 'Squid Game' that are not entirely in accordance with Hobbes' ideas. Such as motivation in the state of human nature (homo homini lupus) and motivation in making social contracts.

At first glance, it can be easily said that the film series 'Squid Game' fully represents Thomas Hobbes' socio-political theory. However, with further understanding and detailing, it can be understood that this film does not fully represent the theory and uses many elements of other political-social theories.

\section{BIBLIOGRAPHY}

Badan Pusat Statistik. Jumlah Penduduk Hasil Proyeksi Menurut Provinsi dan Jenis Kelamin (Ribu Jiwa), 2018-2020. (2020) Badan Pusat Statistik. (n.d.). https://www.bps.go.id/indicator/12/1886/1/jumlah-penduduk-hasil-proyeksi-menurutprovinsi-dan-jenis-kelamin.html.

Bonar Hutapea, Psikologi Politik Hobbesian: Analisis Teoritis tentang Basis Antropologis Kontrak Sosial dalam Leviathan dan relevansinya. (2012) INSAN Vol.No. 01, April 2012.

Dewantara, J. A., Hermawan, Y., Yunus, D., Prasetiyo, W. H., Efriani, Arifiyanti, F., \& Nurgiansah, T. H. (2021). Anti-Corruption Education as an Effort to Form Students With Character Humanist and Law-Compliant. Jurnal Civics: Media Kajian Kewarganegaraan, 18(1), 7081.

Dewantara, J. A., \& Nurgiansah, T. H. (2021a). Building Tolerance Attitudes Of PPKN Students Through Multicultural Education Courses. Jurnal Etika Demokrasi, 6(1), 103-115.

Dewantara, J. A., \& Nurgiansah, T. H. (2021b). Strengthening Pancasila Values During the Covid-19 Pandemic. Edukatif: Jurnal Ilmu Pendidikan, 3(4), 2411-2417.

Mar'ah, Syarifatul. "Representatif Politik Dan Perilaku Legislatif" (2018) https://csws.fisip.unair.ac.id/2018/07/representasi-politik-dan-perilaku-legislatif-stsyarifatul-marah/

Nurgiansah, T. H. (2020). Filsafat Pendidikan. In Banyumas: CV Pena Persada.

Nurgiansah, T. H. (2021). Pendidikan Pancasila. In Solok: CV Mitra Cendekia Media. 
Nurgiansah, T. H., \& Al Muchtar, S. (2018). Development of Student Awareness through Student Learning Model Jurisprudential in Citizenship Education. ATLANTIS PRESS, 251(Acec), 670-674. https://doi.org/10.2991/acec-18.2018.150

Nurgiansah, T. H., Dewantara, J. A., \& Rachman, F. (2020). The Implementation of Character Education in the Civics Education Syllabus at SMA Negeri 1 Sleman. Jurnal Etika Demokrasi, 5(2), 110-121.

Nursanik dan Mursidah. "Kritik Nalar Pemikiran Politik Thomas Hobbes" (2020) 11:2 Jurnal UIN Banten, 18-45.

Rachman, F., Ryan, T., Kabatiah, M., Batubara, A., Pratama, F. F., \& Nurgiansah, T. H. (2021). Pelaksanaan Kurikulum PPKn pada Kondisi Khusus Pandemi Covid-19. Jurnal Basicedu, 5(6), 5682-5691.

Sutanto, O. "Representasi Feminisme Dalam Film “Spy"” (2017) 5:1 Jurnal E-Komunikasi, 22-33

Zulfan. "Pemikiran Politik Thomas Hobbes, John Locke dan J.J. Rousseau tentang Perjanjian Sosial” (2018) 6:2 Serambi Akademica, 30-35. 